\title{
Neural Influence on Protein Kinase C Isoform Expression in Skeletal Muscle
}

\author{
Lutz Hilgenberg, Simone Yearwood, Stuart Milstein, and Kathryn Miles \\ Department of Anatomy and Cell Biology, The State University of New York Health Science Center at Brooklyn, Brooklyn, \\ New York 11203
}

Protein kinase $\mathrm{C}(\mathrm{PKC})$ is a family of enzymes involved in synapse formation and signal transduction at the neuromuscular junction. Two PKC isoforms, classical PKC $\alpha$ and novel PKC $\theta$, have been shown to be enriched in skeletal muscle or localized to the endplate. We examined the role of nerve in regulating the expression of these PKC isoforms in rat skeletal muscle by denervating diaphragm muscle and measuring PKC protein expression at various postoperative times. nPKC $\theta$ protein levels decreased $65 \%$ after denervation, whereas cPKC $\alpha$ levels increased $80 \%$ compared with control hemidiaphragms. These results suggest that innervation regulates PKC $\theta$ and $\alpha$ isoform expression in skeletal muscle. To explore further how nerve regulates PKC expression, we characterized PKC isoform expression in rat myotubes deprived of neural input. Myoblast expression of nPKC $\theta$ was low, and the increase in nPKC $\theta$ expression that occurred during differentia- tion into myotubes resulted in levels of nPKC $\theta$ significantly below adult skeletal muscle. cPKC $\alpha$ expression in myoblasts increased during differentiation to levels that exceeded expression in adult skeletal muscle. Coculturing myotubes with a neuroblastoma $X$ glioma hybrid clonal cell line (NG108-15) increased nPKC $\theta$ expression, but not $\operatorname{cPKC} \alpha$, suggesting that nPKC $\theta$ in skeletal muscle and myotubes is regulated by nerve contact or by a factor(s) provided by nerve. Treating myotubes with tetrodotoxin did not affect either basal- or NG108-15 cell-stimulated nPKC $\theta$ expression. Together these results suggest that expression of $\mathrm{nPKC} \theta$ in skeletal muscle is regulated by a transynaptic interaction with nerve that specifically influences nPKC $\theta$ expression.

Key words: protein kinase C; cPKC $\alpha$; nPKC $\theta$; neuromuscular junction; NG108-15 cells; denervation
Protein phosphorylation is involved in synapse formation and function at the neuromuscular junction. In particular, protein kinase $\mathrm{C}(\mathrm{PKC})$, a $\mathrm{Ca}^{+2}$ - and phospholipid-sensitive protein kinase, has been implicated as a participant in these processes. For example, decreased expression of the nicotinic acetylcholine receptor (nAChR) has been linked to muscle activity and activation of PKC (Klarsfeld et al., 1989; Huang et al., 1992). Application of phorbol esters, which activate PKC, to myotubes inhibits both basal and acetylcholine receptor inducing activity (ARIA)stimulated nAChR synthesis (Burstajn et al., 1988; Altiok et al., 1995). Treatment of myotubes with phorbol esters disrupts spontaneously formed nAChR clusters and abolishes the activity of agrin, an nAChR clustering factor (Burstajn et al., 1988; Ross et al., 1988; Wallace et al., 1991), suggesting that PKC may play a role in the distribution of nAChRs in the postsynaptic membrane. The amplitude of currents induced by the iontophoretic application of acetylcholine to chick myotubes and frog endplates is diminished by the activation of PKC (Eusebi et al., 1985; Caratsch et al., 1986). An accelerated decay in nAChR currents in oocytes injected with nAChR subunit mRNA was obtained by treating oocytes with phorbol esters (Mileo et al., 1995). A reduction in the magnitude of the voltage-gated sodium channel current and a slowing of the current inactivation rate have been attributed to

\footnotetext{
Received March 5, 1996; revised May 29, 1996; accepted May 30, 1996.

This work was supported by U.S. Public Health Service Grant NS29356 to K.M. We thank Drs. George Ojakian and Michael Wagner for critically reading this manuscript.

Correspondence should be addressed to Kathryn Miles, Department of Anatomy and Cell Biology, The State University of New York Health Science Center at Brooklyn, Brooklyn, NY 11203.

Copyright (C) 1996 Society for Neuroscience $0270-6474 / 96 / 164994-10 \$ 05.00 / 0$
}

phosphorylation of the sodium channel by PKC in myotubes (Numann et al., 1994). Although the phosphorylation events that mediate these effects have not yet been identified, several important molecules in the neuromuscular junction have been demonstrated to be substrates for PKC. PKC phosphorylates the Torpedo $\mathrm{nAChR}$ in vitro (Safran et al., 1987), whereas PKC may be directly or indirectly responsible for phosphorylating the nAChR in myotubes (Ross et al., 1988; Miles et al., 1994). Potential PKC phosphorylation sites have been identified on the nAChR $\delta$ subunit and on the adult skeletal muscle sodium channel $\alpha$ subunit (Miles and Huganir, 1988; Bendahhou et al., 1995). Neither the first messenger that stimulates PKC activity nor the PKC isoforms involved in phosphorylating substrates in the neuromuscular junction have yet been identified.

The PKC family of enzymes is comprised of multiple isoforms, each encoded by a separate gene. PKC isoforms consist of a single polypeptide chain and are grouped according to the homologous amino acid sequences contained within their regulatory and catalytic domains (Nishizuka, 1992; Hug and Sarre, 1993; Newton, 1995). Classical PKCs (cPKC) contain a calcium-binding or selectivity (C2) domain that is absent in the novel PKCs (nPKC). Both classic and novel isoforms of PKC contain a binding site $(\mathrm{C} 1)$ for diacylglycerol and phorbol ester, each of which stimulates kinase activity. The multiplicity of PKC isoforms and their differences in tissue distribution raise the question as to whether they function distinctly within different tissues or cells.

Skeletal muscle is enriched for the mRNA encoding cPKC $\alpha$ and $\mathrm{nPKC} \theta$ compared with other known isoforms of $\mathrm{PKC}$, suggesting that these are the most abundant $\mathrm{PKC}$ isoforms present in this tissue (Osada et al., 1992). cPKC $\alpha$ appears to be ubiquitously 
expressed, whereas $\mathrm{nPKC} \theta$ is exclusively expressed in skeletal muscle, hematopoietic tissue, and testes (Osada et al., 1992; Baier et al., 1993; Chang et al., 1993; Mischak et al., 1993; Hilgenberg and Miles, 1995). Previously, our laboratory demonstrated that nPKC $\theta$ expression is developmentally regulated in postnatal skeletal muscle and is localized to the neuromuscular junction (Hilgenberg and Miles, 1995). These results suggested that nPKC $\theta$ may be specifically involved in events associated with maturation of the neuromuscular junction. To explore further the potential role of these two PKC isoforms in skeletal muscle and the neuromuscular junction, we sought to determine the cellular mechanisms that influence their expression.

We investigated whether nerve regulates $\mathrm{PKC}$ expression and found that $\mathrm{nPKC} \theta$ levels decreased whereas $\mathrm{cPKC} \alpha$ levels increased after denervation of skeletal muscle. To delineate further the underlying mechanisms responsible for these changes, we explored PKC isoform expression in aneural myotubes. nPKC $\theta$ expression in myoblasts was significantly below levels detected in adult skeletal muscle and remained so after myogenic differentiation, suggesting that the absence of nerve deprives myotubes of a factor(s) influencing expression of this isoform. Coculture of myotubes with a neuroblastoma $\mathrm{X}$ glioma hybrid clonal cell line (NG108-15) (Christian et al., 1977) that is capable of forming functional synapses on myotubes resulted in significantly enhanced expression of nPKC $\theta$ by the myotubes. These observations support the hypothesis that nPKC $\theta$ expression is regulated transynaptically at the neuromuscular junction and that this PKC isoform plays a role in the formation and function of this synapse.

\section{MATERIALS AND METHODS}

Denervation or nerve crush of rat skeletal muscle. Adult Sprague-Dawley rats $(300-500 \mathrm{gm})$ were anesthetized with sodium pentobarbital and unilateral denervation, or nerve crush was performed on hemidiaphragms via a thoracic incision. A 3-5 mm segment of the phrenic nerve was either excised or crushed with a forceps within $2 \mathrm{~mm}$ of its entrance into the diaphragm. The wounds were sutured, and the rats were allowed to recover.

Tissue culture. Rat primary myotube cultures were established from hindlimb muscles of 20-21 d embryos as described previously (Miles et al., 1994). Myoblasts were plated on collagen-coated $35 \mathrm{~mm}$ tissue culture dishes unless otherwise stated and were grown in DMEM supplemented with $20 \%$ (v/v) fetal calf serum (FCS) and $33 \mathrm{~mm}$ glucose. After $2 \mathrm{~d}$, this medium was replaced with medium containing $10 \%(\mathrm{v} / \mathrm{v})$ horse serum and $2 \%(\mathrm{v} / \mathrm{v})$ chicken embryo extract. Primary rat fibroblast cultures were established by preplating an embryonic hindlimb muscle cell preparation for $1 \mathrm{hr}$ on non-collagen-coated tissue culture dishes and then gently washing off the myoblasts. The remaining fibroblast-enriched cultures were treated according to the same regimen as for primary myoblast/ myotube cultures. National Institutes of Health $3 \mathrm{~T} 3$ cells were grown in DMEM with $10 \%$ FCS. NG108-15 cells, a gift from M. Nirenberg (National Institutes of Health, Bethesda, MD), were grown in DMEM containing $1 \times$ hypoxanthine-aminopterin-thymidine and $10 \%$ FCS on tissue culture dishes. NG108-15 cells were induced to differentiate, when they reached $80 \%$ confluency, by applying differentiation medium composed of NG108-15 cell growth medium containing $200 \mu \mathrm{M}$ isobutylmethylxanthine (Sigma, St. Louis, MO) and 5\% horse serum substituted for FCS. Cocultures were established by adding dispersed NG108-15 cells in growth medium to primary myotube cultures. After a few hours to permit adhesion of the NG108-15 cells, the medium was removed and replaced with NG108-15 cell differentiation medium. Indirect cocultures were established by plating NG108-15 cells onto collagen-coated tissue culture inserts (Nunc, Naperville, IL), allowing the NG108-15 cells to differentiate, and then placing the inserts onto myotube cultures. The tissue culture inserts were composed of $45-\mu \mathrm{m}$-thick polycarbonate semipermeable membranes, containing pores of determined sizes, that provided a surface for cell adhesion and growth. The inserts rested $1 \mathrm{~mm}$ above the underlying tissue culture dish, thereby separating the cells growing on the membrane from those on the tissue culture dish while permitting the exchange of medium and diffusible factors. The two cell populations can be assayed separately. During indirect coculture of myotubes and NG108-15 cells, both the cocultures and control myotubes were cultured in NG108-15 cell differentiation medium. NG108-15 cell-conditioned medium was obtained by collecting medium from NG108-15 cells cultured for $3 \mathrm{~d}$ in differentiation medium. The medium was centrifuged for $15 \mathrm{~min}$ at $1000 \times \mathrm{g}$, and the supernatant was added in place of myotube differentiation medium. All cultures were maintained at $37^{\circ} \mathrm{C}$ in a $5 \%$ $\mathrm{CO}_{2}$ atmosphere.

Subcellular fractionation of rat skeletal muscle and cells in culture. Rat diaphragms were dissected, rinsed in $\mathrm{PBS}$ at $4^{\circ} \mathrm{C}$, frozen in liquid nitrogen, and pulverized using a mortar and pestle. The powdered tissue was homogenized, using a Dounce homogenizer, in Buffer A $(10 \mathrm{ml} / \mathrm{gm}$ wet weight) containing $20 \mathrm{~mm}$ Tris, pH 7.5, $10 \mathrm{~mm}$ EDTA, 10 mM EGTA, 25 $\mu \mathrm{g} / \mathrm{ml}$ aprotinin, $50 \mu \mathrm{g} / \mathrm{ml}$ leupeptin, $10 \mathrm{~mm}$ benzamidine, $10 \mathrm{~mm}$ phenylmethylsulfonyl fluoride, and $10 \mathrm{~mm} \beta$-mercaptoethanol. Cells in culture were scraped from the dish and homogenized in Buffer A (75 $\mu 1 / 35$ $\mathrm{mm}$ tissue culture dish). The homogenates were centrifuged at $6000 \times \mathrm{g}$ for $2 \mathrm{~min}$, and supernatants were collected and centrifuged at 95,000 $\times g$ for $45 \mathrm{~min}$. The resulting supernatants (cytosolic fractions) were collected, and the pellets (membrane fractions) were solubilized in Buffer A containing 1\% Triton X-100 (30 $\mu \mathrm{l} /$ pellet). Samples were adjusted such that either an equal amount of total protein (PKC expression per $\mu \mathrm{g}$ protein) or an equal representative volume (PKC expression per tissue culture dish) from each of these two fractions was analyzed as indicated. Protein concentrations were determined using the Bio-Rad (Hercules, CA) protein assay based on Coomassie brilliant blue binding. NG108-15 cell membrane fractions were obtained from cells cultured for several days in differentiation medium, homogenized in PBS instead of Buffer A, and centrifuged as described above. The pellet from the high-speed centrifugation was resuspended in PBS and applied to myotubes.

Immunoblot analysis. Proteins were subjected to SDS-PAGE $(8.5 \%)$ and then transferred electrophoretically to nitrocellulose membranes. The membranes were incubated overnight at $4^{\circ} \mathrm{C}$ in Blotto buffer containing $200 \mathrm{~mm} \mathrm{NaCl}, 50 \mathrm{~mm}$ Tris, $0.1 \%$ Triton X-100, $0.2 \%$ Tween-20, 5\% nonfat dry milk (w/v), and $0.4 \%$ Ficoll-400, pH 7.4, to block nonspecific binding. nPKC $\theta$ was detected using S22 antiserum (Hilgenberg and Miles, 1995). cPKC $\alpha$ was detected using a previously characterized monoclonal antibody, M6 (Leach et al., 1988) (UBI, Lake Placid, NY), followed by a rabbit anti-mouse secondary antibody (Dako, Carpinteria, CA). Membranes were then incubated with ${ }^{125} \mathrm{I}$ labeled protein A (ICN Biochemicals, Costa Mesa, CA), washed, and exposed to X-ray film. Radioactivity was quantitated using a PhosphorImager and ImageQuant software (Molecular Dynamics, Sunnyvale, CA). The area to be quantitated was defined visually, and identical areas were used to quantitate sample as well as background for each PKC isoform. Background and maximal PhosphorImager measurements obtained were in the range of 500 to 10,000 units, respectively. The data obtained were within the linear range of the assay and the instrument for each experiment.

$\alpha$-Bungarotoxin binding assay. nAChR were assayed using $\left[{ }^{125} \mathrm{I}\right] \alpha$ bungarotoxin (DuPont NEN, Boston, MA) in cultures solubilized in 1\% Triton X-100 according to established methods (Schmidt and Raftery, 1973).

Northern blot analysis. Rat skeletal muscle was dissected, frozen in liquid nitrogen, and pulverized. Total RNA was extracted from frozen pulverized tissue or from cells in culture using RNAzol (Tel-Test, Friendswood, TX). Poly $\left(\mathrm{A}^{+}\right)$-enriched RNA, isolated by oligo-dT chromatography, was electrophoresed through $0.8 \%$ agarose gels containing $7 \%$ formaldehyde and transferred to Hybond- $\mathrm{N}^{+}$nylon membranes (Amersham, Arlington Heights, IL). Membranes were hybridized overnight at $65^{\circ} \mathrm{C}$ with a ${ }^{32} \mathrm{P}$-random-primed labeled cDNA probe encoding $\mathrm{nPKC} \theta$, kindly provided by Shin-ichi Osada (Vanderbilt University, Nashville, TN) (nt -23-2262; Genbank accession number D11091) in a buffer containing $50 \mathrm{~mm}$ polyethylene glycol $8000,7 \%$ SDS, $1.5 \times$ SSPE, and 250 $\mu \mathrm{g} / \mathrm{ml}$ salmon sperm DNA. The membranes were washed at $65^{\circ} \mathrm{C}$ in $0.2 \times$ SSC containing $0.1 \%$ SDS and exposed for autoradiography. Some blots were reprobed under the same conditions with a ${ }^{32} \mathrm{P}$-random-primed labeled 250 bp fragment of the mouse cardiac $\alpha$-actin gene (nt 940-1190; Leader et al., 1986; Genbank accession number M15501), kindly provided by L. Moscoso and J. Sanes (Washington University, St. Louis, MO). This actin probe cross-hybridizes with skeletal muscle actins. 

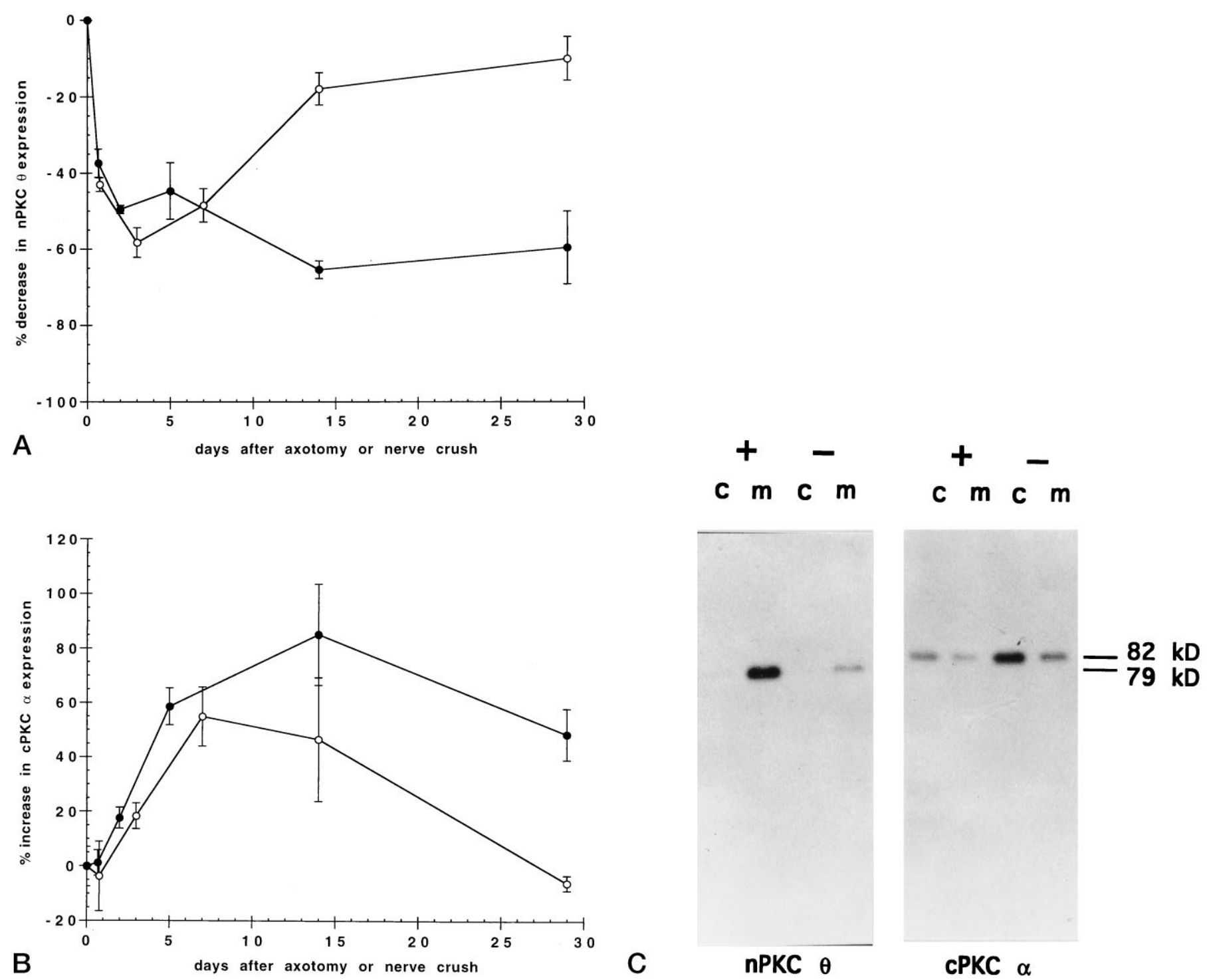

Figure 1. Time course of nerve crush or axotomy on PKC expression in skeletal muscle. The phrenic nerve to rat diaphragm muscle was unilaterally severed (axotomy) $(\bullet)$ or crushed $(\bigcirc)$, and the rats were allowed to recover for the indicated times. Diaphragms were then removed, homogenized, and separated into cytosolic and membrane protein fractions by ultracentrifugation. Cytosolic $(c)$ and membrane $(m)$ proteins $(50 \mu \mathrm{g})$ from both denervated and control hemidiaphragms from each rat were separated by SDS-PAGE and transferred to nitrocellulose membranes. Immunoblots were probed with antiserum specific to nPKC $\theta(A)$ or antibody specific to cPKC $\alpha(B)$ followed by a secondary antibody and ${ }^{125}$ I-labeled protein A. The blots were exposed for autoradiography, and radioactivity was quantitated by PhosphorImager analysis using ImageQuant software. Data are expressed as percent decrease in nPKC $\theta(A)$ or increase in cPKC $\alpha(B)$ expression in cytosolic plus membrane fractions of experimental compared with control hemidiaphragms of the same rat. Error bars represent SEM. For each point, $n=3$ or 4 rats. $C$ shows a representative autoradiogram of an immunoblot from $14 \mathrm{~d}$ axotomized $(-)$ and control $(+)$ hemidiaphragms.

\section{RESULTS}

\section{PKC isoform expression is altered after rat skeletal muscle denervation}

To explore the role of nerve in regulating PKC isoform expression, we unilaterally severed or crushed the phrenic nerve to rat diaphragm muscle and measured PKC expression at various times during postoperative recovery. $\mathrm{nPKC} \theta$ expression relative to total protein in hemidiaphragms was found to decrease rapidly, reaching a maximal decrease of $65 \% 2$ weeks after nerve cut compared to the untreated hemidiaphragm in the same rat (Fig. $1 A$ ). Temporary denervation, in the form of nerve crush, led initially to a decrease in nPKC $\theta$ expression with the same time course observed after nerve cut, followed by a recovery in expression over a 2 week time period (Fig. $1 A$ ). These data suggest that expression of nPKC $\theta$ in skeletal muscle is regulated by innervation.

In contrast, cPKC $\alpha$ expression was found to increase $80 \%$ in hemidiaphragms $14 \mathrm{~d}$ after nerve cut compared with control hemidiaphragms (Fig. $1 B$ ). cPKC $\alpha$ protein levels were also observed to increase initially after nerve crush followed by a return to control levels after 4 weeks (Fig. 1B). The increase in cPKC $\alpha$ expression after nerve crush occurred at an initial rate that paralleled the increase in cPKC $\alpha$ seen after nerve cut but was slower than the changes in nPKC $\theta$ expression induced by denervation. Taken together, these results demonstrate that PKC $\alpha$ and $\theta$ isoforms are differentially regulated in skeletal muscle by innervation. 


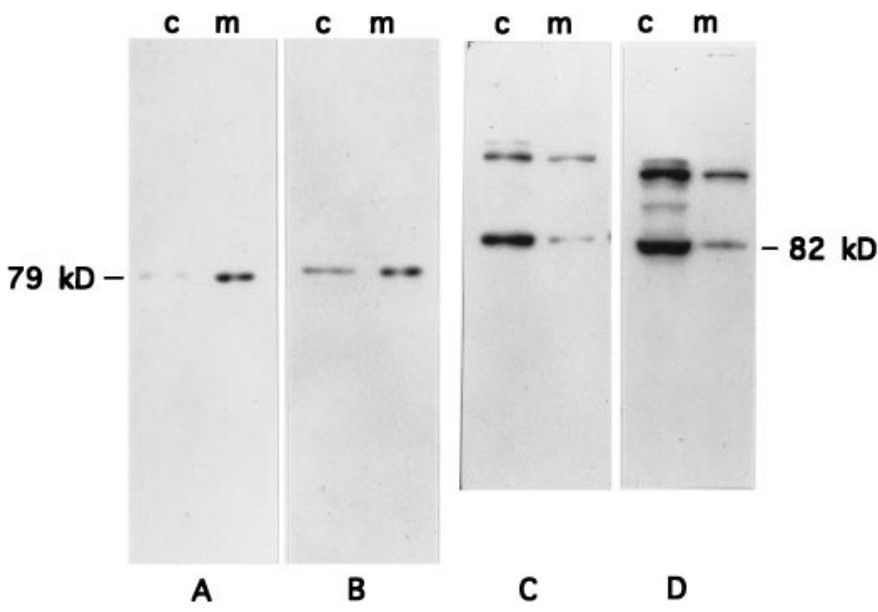

Figure 2. Subcellular distribution of PKC $\theta$ and $\alpha$ isoforms in primary rat myotubes. Primary myoblast cultures were established and cultured for $8 \mathrm{~d}$ to permit differentiation into myotubes. Myotube cultures were homogenized and separated into cytosolic $(c)$ and membrane $(m)$ protein fractions by ultracentrifugation. Fractions were adjusted either to equal protein concentration $(A, C, 100 \mu \mathrm{g} /$ lane $)$ or to equal volume $(B, D, 100 \mu \mathrm{l} /$ lane $)$ and were separated by SDS-PAGE and transferred to nitrocellulose membranes. The immunoblots were probed with anti-nPKC $\theta$ antiserum $(A, B)$ or anti-cPKC $\alpha$ antibody $(C, D)$ as described in the legend to Figure 1 and were exposed for autoradiography. nPKC $\theta$ and $\mathrm{cPKC} \alpha$ migrate as 79 and $82 \mathrm{kDa}$ proteins, respectively.

It is possible that denervation affects $\mathrm{PKC}$ isoform expression in skeletal muscle due to the absence of nerve-evoked muscle activity and/or nerve-derived trophic factors as well as by the initiation of mononuclear cell proliferation. We turned to primary rat myotubes in culture as a strategy to explore these mechanisms.

\section{PKC isoform distribution in rat primary myotubes in culture}

Basal expression of PKC isoforms in cytosolic and membrane subcellular fractions from cultured myotubes devoid of neural input was analyzed to characterize this experimental model for exploring PKC isoform expression. $\mathrm{nPKC} \theta(79 \mathrm{kDa})$ expression, per $\mu \mathrm{g}$ protein, was found to be concentrated in the membrane fraction of primary myotube cultures (Fig. 2A) but varied in extent between preparations. nPKC $\theta$ expression, per culture, was also greater in the membrane fraction rather than the cytosolic fraction of myotube cultures (Fig. $2 B$ ). This distribution profile is similar to that observed for nPKC $\theta$ in adult skeletal muscle (Hilgenberg and Miles, 1995).

In contrast, expression of $\mathrm{cPKC} \alpha(82 \mathrm{kDa})$ in myotube cultures was found to be distributed predominantly in the cytosolic fraction regardless of whether expression was assayed per $\mu \mathrm{g}$ protein (Fig. $2 C$ ) or per culture (Fig. $2 D$ ). This isoform distribution is also similar to that seen in adult skeletal muscle (Hilgenberg and Miles, 1995). Immunoblots of $\mathrm{cPKC} \alpha$ from cultured cells using the M6 antibody resulted in the detection of higher-molecularweight proteins of unknown identity that are not seen in adult skeletal muscle (Figs. $1 C, 2 C, D, 6 C, D$ ).

\section{PKC isoform protein expression during myogenic differentiation}

To determine whether PKC isoform expression in skeletal muscle is influenced by myogenic differentiation, we analyzed PKC isoform levels in cultures in which myoblasts were undergoing terminal differentiation to myotubes. In addition, these experiments also address the issue of whether muscle cell activity plays a role in PKC expression because well differentiated myotubes in culture contract spontaneously. Myotube differentiation in culture was monitored by measuring nAChR levels. Expression of nAChRs increased 10-fold between days 2 and 9 in culture (Fig. $3 A$ ), in accordance with previous studies (Evans et al., 1987).

$\mathrm{nPKC} \theta$ expression in myoblast culture membrane fractions was $90 \%$ below levels in adult skeletal muscle membrane fractions and increased only slightly during myogenic differentiation (Fig. $3 B$ ). Because of spontaneous contractions, myotubes rarely survived beyond $9 \mathrm{~d}$. In cultures that did survive $14 \mathrm{~d}$, nPKC $\theta$ expression was not found to exceed $15-20 \%$ of adult skeletal muscle levels. This result is consistent with the observation that nPKC $\theta$ expression is reduced in diaphragms after denervation (Fig. $1 A$ ). Cytosolic fractions of myotube cultures had barely detectable levels of nPKC $\theta$ throughout differentiation (data not shown), and this isoform was not detected in primary fibroblast cultures. Taken together, these data suggest that myogenic differentiation and spontaneous muscle cell activity do not promote adult skeletal muscle levels of nPKC $\theta$ expression in myotubes.

In parallel cultures, cPKC $\alpha$ protein expression in the cytosol was found to increase fivefold from days 2 to 6 in culture, concomitant with cell fusion and the increase in nAChRs (Fig. $3 C$ ). cPKC $\alpha$ was found to be maximally expressed in myotubes at a significantly higher level than that seen in adult skeletal muscle. An increase in cPKC $\alpha$ levels also was seen in the membrane fraction of myotube cultures such that the proportion of cytosolic to membrane cPKC $\alpha$ expression did not change (data not shown). These results, obtained in aneural myotube cultures, are consistent with the previous experiments in which cPKC $\alpha$ expression in denervated diaphragm muscle increased by $80 \%$ (Fig. 1B). The increase in $\mathrm{cPKC} \alpha$ expression coinciding with myogenic differentiation is consistent with a role for this $\mathrm{PKC}$ isoform in this process. These data also suggest that innervation may suppress cPKC $\alpha$ expression.

In our experiments, myotube cultures are composed of $80-90 \%$ myotubes. Nevertheless, to determine whether the changes in cPKC $\alpha$ expression during myoblast differentiation in culture are attributable to the proliferation of fibroblasts present in primary cultures rather than to myotubes, $\mathrm{cPKC} \alpha$ expression was measured in the cytosolic and membrane fractions of primary fibroblast cultures devoid of myotubes during the same period in culture. Levels of cPKC $\alpha$ in primary fibroblasts were elevated only slightly compared with adult skeletal muscle and did not change significantly over this culture period (data not shown). These data rule out the possibility that primary fibroblast proliferation accounts for the increase in cPKC $\alpha$ expression observed in differentiating myoblast cultures and support the hypothesis that $\mathrm{cPKC} \alpha$ plays a role in proliferation of muscle cell precursors and myogenic differentiation.

\section{nPKC $\theta$ mRNA transcript expression during myogenic differentiation}

To determine whether the expression pattern of nPKC $\theta$ observed during myogenic differentiation also occurred at the mRNA transcript level, analysis of the mRNA transcripts encoding nPKC $\theta$ was performed and compared in postnatal day 0 and adult skeletal muscle as well as myoblasts and myotubes (Fig. 4). mRNA transcript levels for nPKC $\theta$ were low in postnatal day 0 skeletal muscle but increased severalfold in adult skeletal muscle (Fig. 4), supporting previous observations that postnatal expression of nPKC $\theta$ protein is developmentally regulated (Hilgenberg and Miles, 1995). nPKC $\theta$ mRNA transcripts were undetectable in 

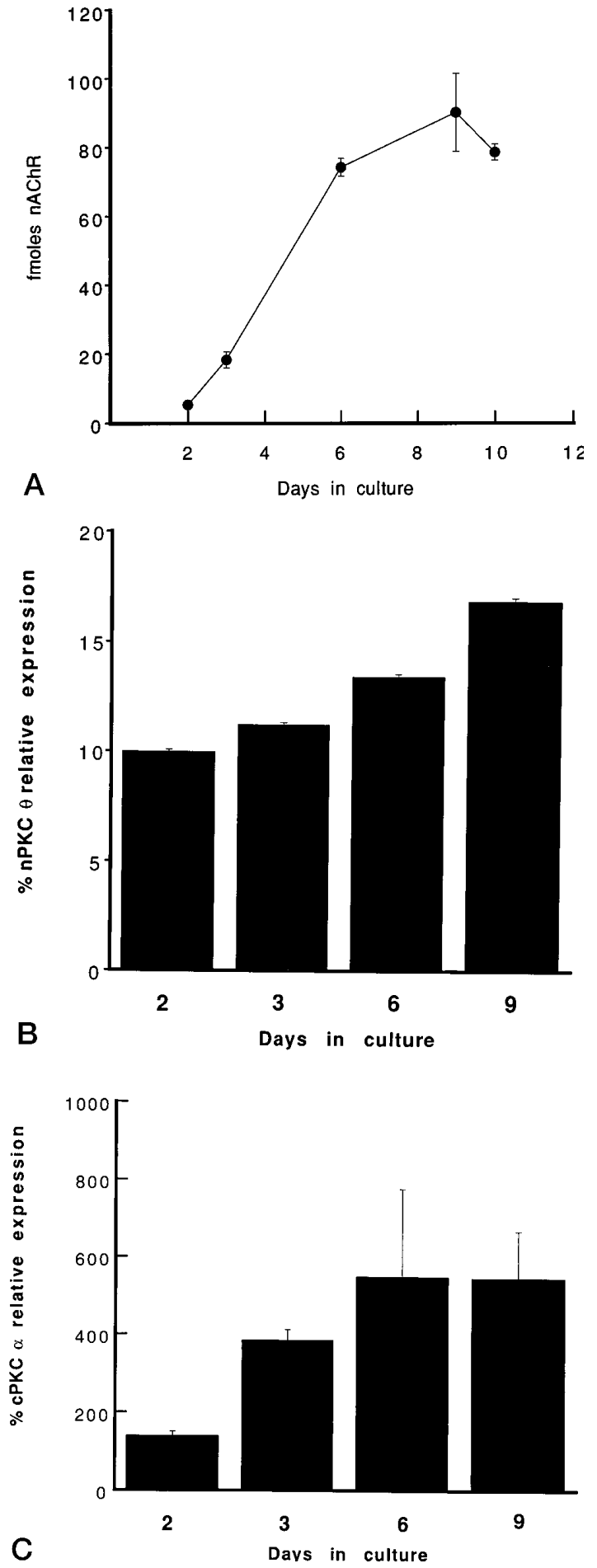

Figure 3. Time course of the expression of nAChRs and PKC $\alpha$ and $\theta$ isoforms during myogenic differentiation in culture. Primary myoblast cultures were established in parallel. At the indicated days in culture, cells were solubilized and specific binding of $\left[{ }^{125} \mathrm{I}\right] \alpha$-bungarotoxin to $\mathrm{nAChRs}$ was quantitated. Data are expressed as fmol of nAChR per $35 \mathrm{~mm}$ tissue culture dish $(A)$. Alternatively, cells were homogenized and membrane $(B)$ or cytosolic $(C)$ proteins were separated by SDS-PAGE and transferred to nitrocellulose membranes. The immunoblots were probed with anti-PKC $\theta$ antiserum $(B)$ or anti-PKC $\alpha$ antibody $(C)$ and analyzed according to the legend to Figure 1. PKC isoform levels in membrane or cytosolic subcellular fractions $(100 \mu \mathrm{g} / \mathrm{lane})$ of cultured cells are expressed as percent PKC isoform expression in membrane $(B)$ or cytosolic $(C)$ protein $(100$ $\mu \mathrm{g} /$ lane) fractions of adult skeletal muscle, respectively. Each experiment was performed in triplicate. Error bars represent SEM.

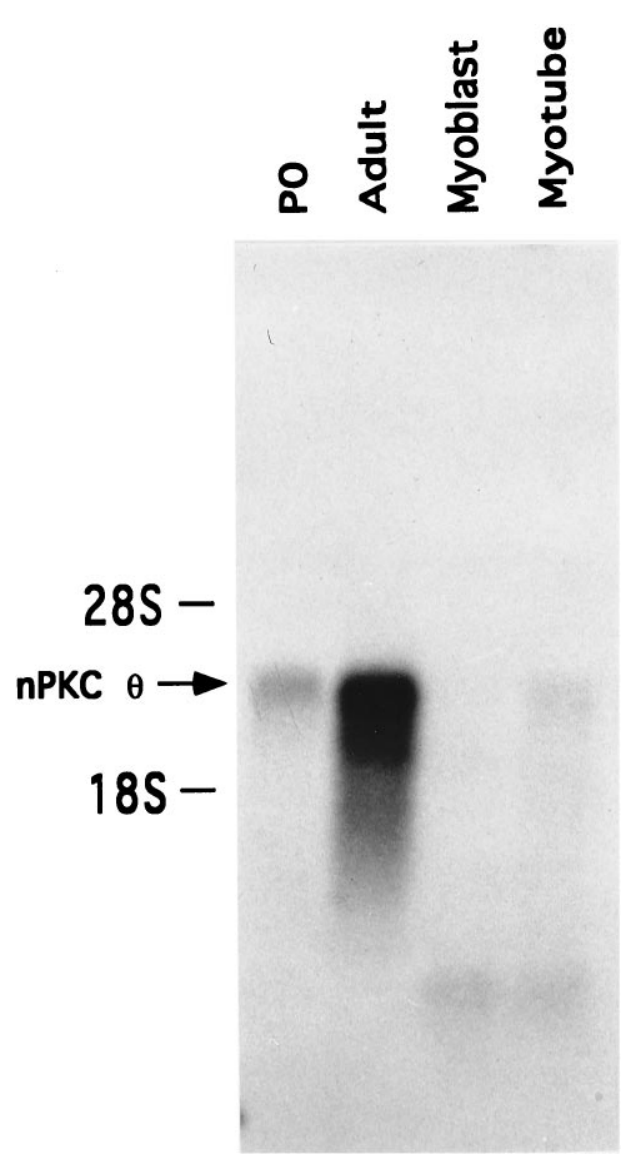

Figure 4. Developmental regulation of nPKC $\theta$ mRNA transcripts in skeletal muscle and primary myoblast and myotube cultures. Total RNA from rat postnatal day 0 skeletal muscle (P0), adult skeletal muscle, and primary myoblast (day 1 in culture) and myotube (day 7 in culture) cultures was isolated and quantitated. Poly $\left(\mathrm{A}^{+}\right)$-enriched RNA obtained from total RNA ( $300 \mu \mathrm{g})$ from each sample was isolated, electrophoresed, and transferred to nylon membranes. Blots were probed with ${ }^{32} \mathrm{P}$-labeled $\mathrm{nPKC}$ $\theta$ cDNA and were exposed for autoradiography. This figure represents one of three identical experiments.

myoblasts and appeared only at low levels in differentiated myotubes (Fig. 4). These observations parallel those in which protein expression of $\mathrm{nPKC} \theta$ in myotubes was found to be significantly less than that in adult skeletal muscle (Fig. 3B). These data further argue that differentiation of skeletal muscle and/or spontaneous muscle cell activity is not sufficient to induce adult levels of expression of the nPKC $\theta$ isoform. A more likely possibility is that $\mathrm{nPKC} \theta$ expression is regulated by an interaction with nerve.

\section{PKC protein expression in myotubes cocultured with NG108-15 cells}

To explore further the role of nerve in regulating $\mathrm{PKC}$ isoform expression, myotubes were cocultured in the presence of NG108-15 cells, a neuroblastoma X glioma hybrid cell line that has been shown previously to make synaptic contacts on myotubes in culture (Christian et al., 1977). Coculture of myotubes with NG108-15 cells for $2.5 \mathrm{~d}$ caused a maximal 3.5-fold increase in nPKC $\theta$ protein levels (Fig. 5). The initial increase and subsequent plateau of nPKC $\theta$ protein in cocultured myotubes suggest that myotubes were exposed to rising and subsequently saturating levels of either contact with or a factor(s) provided by NG108-15 cells that increases nPKC $\theta$ expression in myotubes. Coculturing myotubes with National Institutes of Health $3 \mathrm{~T} 3$ cells, a trans- 


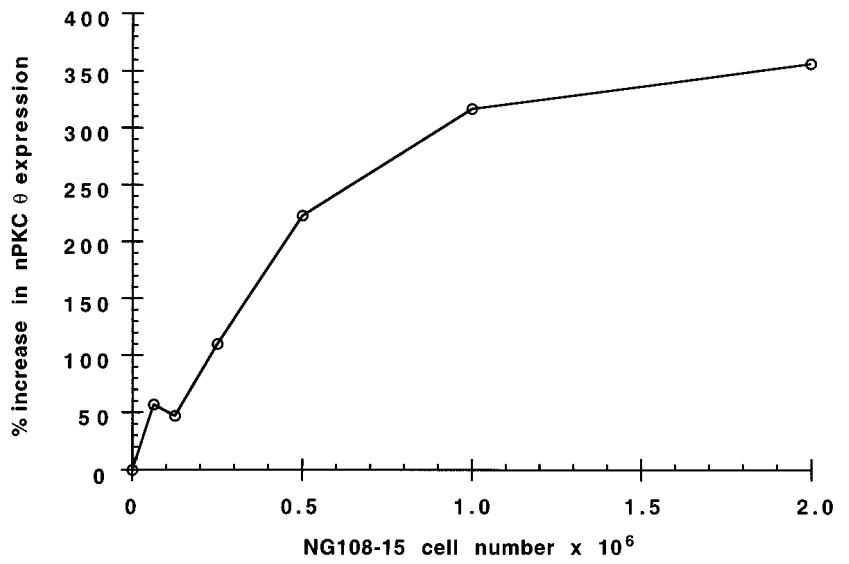

Figure 5. Effect of coculture of myotubes with NG108-15 cells on nPKC $\theta$ expression. Primary myoblast cultures were established and cultured for $7 \mathrm{~d}$ as described in the legend to Figure 2. Myotubes were then cocultured for $2.5 \mathrm{~d}$ in the presence of the indicated number of NG108-15 cells. The cultures were homogenized and centrifuged at $6000 \times g$ for $2 \mathrm{~min}$. Proteins contained in equal representative volumes from each supernatant were separated by SDS-PAGE, transferred to nitrocellulose membranes, and analyzed according to the legend to Figure 1. Data are expressed as percent increase in nPKC $\theta$ expression compared with parallel myotubes cultured in NG108-15 cell differentiation medium without NG108-15 cells. For each point, $n=1$.

formed fibroblast cell line, had no effect on nPKC $\theta$ expression (data not shown). In addition, NG108-15 cells did not affect nPKC $\theta$ expression in fibroblast preplate cultures lacking myotubes (data not shown). Taken together, these data suggest that NG108-15 cells increased nPKC $\theta$ synthesis in myotubes.

NG108-15 cells expressed detectable levels of cPKC $\alpha$, whereas nPKC $\theta$ could not be detected by us in these cells. To control for the possibility that the increase in $\mathrm{nPKC} \theta$ expression detected in cocultures was attributable to the induction of NG108-15 cells, rather than myotubes, to express nPKC $\theta$ after coculture with myotubes, and to examine cPKC $\alpha$ expression in myotubes after exposure to NG108-15 cells, experiments were performed in which NG108-15 cells were indirectly cocultured with myotubes (see Materials and Methods). NG108-15 cells and myotubes were cultured in the same culture dish but were separated from each other by semipermeable membranes of defined pore sizes. Diffusion of medium and soluble factors, but probably not direct cell contact, between these two cell populations is possible with 0.2 $\mu \mathrm{m}$ pore size membranes. Larger size pores, 3 and $8 \mu \mathrm{m}$, are likely to have facilitated passage of large molecules as well as NG108-15 cell neuritic processes that may contact myotubes. After indirect coculture with NG108-15 cells, using 3 or $8 \mu \mathrm{m}$ pore size membranes, a 3- and 3.7-fold increase, respectively, in nPKC $\theta$ expression was detected in myotube membrane fractions compared with noncocultured myotube membrane fractions (Fig. $6 \mathrm{~A}$; SEM for 3 $\mu \mathrm{m}$ : 0.06 , SEM for $8 \mu \mathrm{m}: 0.04 ; n=3$ for both tissue culture inserts). Increased $\mathrm{nPKC} \theta$ expression was also found in the cytosolic fraction of myotubes indirectly cocultured with NG108-15 cells but to a lesser extent than that seen in the membrane fraction (Fig. $6 B$ ). No nPKC $\theta$ was detected in membrane or cytosolic fractions (Fig. 6A,B) from NG108-15 cells indirectly cocultured with myotubes. Expression of cPKC $\alpha$ did not change in either the membrane or the cytosolic fraction of myotubes indirectly cocultured with NG108-15 cells (Fig. 6C,D), and total protein expression in myotubes indirectly cocultured with NG108-15 cells was indistinguishable from control myotube cultures (data not shown). Taken together, these results further support the hypothesis that NG108-15 cells specifically increase nPKC $\theta$ expression in myotubes.

The extent to which NG108-15 cells were able to stimulate an increase in $\mathrm{nPKC} \theta$ expression was found to be dependent on the pore size of the semipermeable membrane separating the two cultures; a 70-80\% increase in $\mathrm{nPKC} \theta$ expression was detected in myotubes separated from NG108-15 cells by a $0.2 \mu \mathrm{m}$ pore size membrane compared with a $250 \%$ increase observed using membranes of 3 and $8 \mu \mathrm{m}$ pore sizes (Fig. 7). These results suggest that a diffusible factor(s) less able to pass through a $0.2 \mu \mathrm{m}$ than a 3 or $8 \mu \mathrm{m}$ opening, and/or cell contact resulting from NG108-15 cell processes protruding through the larger size pores, is responsible for stimulating $\mathrm{nPKC} \theta$ expression in myotubes.

To pursue the possibility that a diffusible factor from NG108-15 cells stimulates nPKC $\theta$ expression in myotubes, conditioned medium from differentiated NG108-15 cells was applied to myotubes and was not found to increase nPKC $\theta$ levels significantly compared with control myotubes (Fig. 7). Subcellular membrane fractions from NG108-15 cells were more potent than conditioned medium in increasing nPKC $\theta$ expression in myotubes, suggesting that this effect is mediated by a factor(s) that is membraneassociated rather than diffusible. The observation that NG108-15 cells separated from myotubes by 3 and $8 \mu \mathrm{m}$ filters resulted equally in an enhanced nPKC $\theta$ expression that significantly surpassed that of intact cells separated by a $0.2 \mu \mathrm{m}$ filter, in which direct cell contact is expected to be minimal, further supports this hypothesis. However, because NG108-15 cell subcellular membrane fractions had a potency equal to that of intact cells separated by a $0.2 \mu \mathrm{m}$ filter, it is also possible that the factor(s) is diffusible but labile and must be continuously replenished.

\section{nPKC $\theta$ mRNA transcript expression in myotubes cocultured with NG108-15 cells}

To establish whether the increased nPKC $\theta$ protein expression observed in myotubes cocultured with NG108-15 cells also occurred at the mRNA transcript level, nPKC $\theta$ transcripts were measured in myotubes cocultured with NG108-15 cells. A 2.5-fold increase in nPKC $\theta$ mRNA was detected in myotubes cocultured with NG108-15 cells compared with control myotube cultures (Fig. 8). No nPKC $\theta$ mRNA transcripts were detected in NG108-15 cell populations (Fig. 8). These results suggest that regulation of nPKC $\theta$ expression in myotubes by NG108-15 cells occurs at the mRNA transcript level. mRNA transcript levels for the skeletal muscle isoform of $\alpha$-actin indicate that differences in mRNA from myotubes cannot account for the increase in nPKC $\theta$ mRNA detected in cocultures (Fig. 8).

\section{Role of myotube activity on $\mathrm{nPKC} \boldsymbol{\theta}$ expression}

To examine further whether muscle activity plays a role in nervedependent expression of $\mathrm{nPKC} \theta$, myotubes were preincubated with tetrodotoxin (TTX) to block spontaneous contractions. Application of TTX to cultures silenced myotube contractions but had little effect on basal nPKC $\theta$ expression in myotubes (Fig. 9). Moreover, the presence of TTX failed to alter the extent to which subcellular membrane fractions from NG108-15 cells stimulated nPKC $\theta$ expression in myotubes (Fig. 9). These data confirm our observation that the acquisition of contractile activity in myotubes had only a minor effect on nPKC $\theta$ protein expression. Furthermore, these data support the hypothesis that nPKC $\theta$ expression in skeletal muscle is mediated by an interaction between muscle and nerve that is independent of muscle activity. 


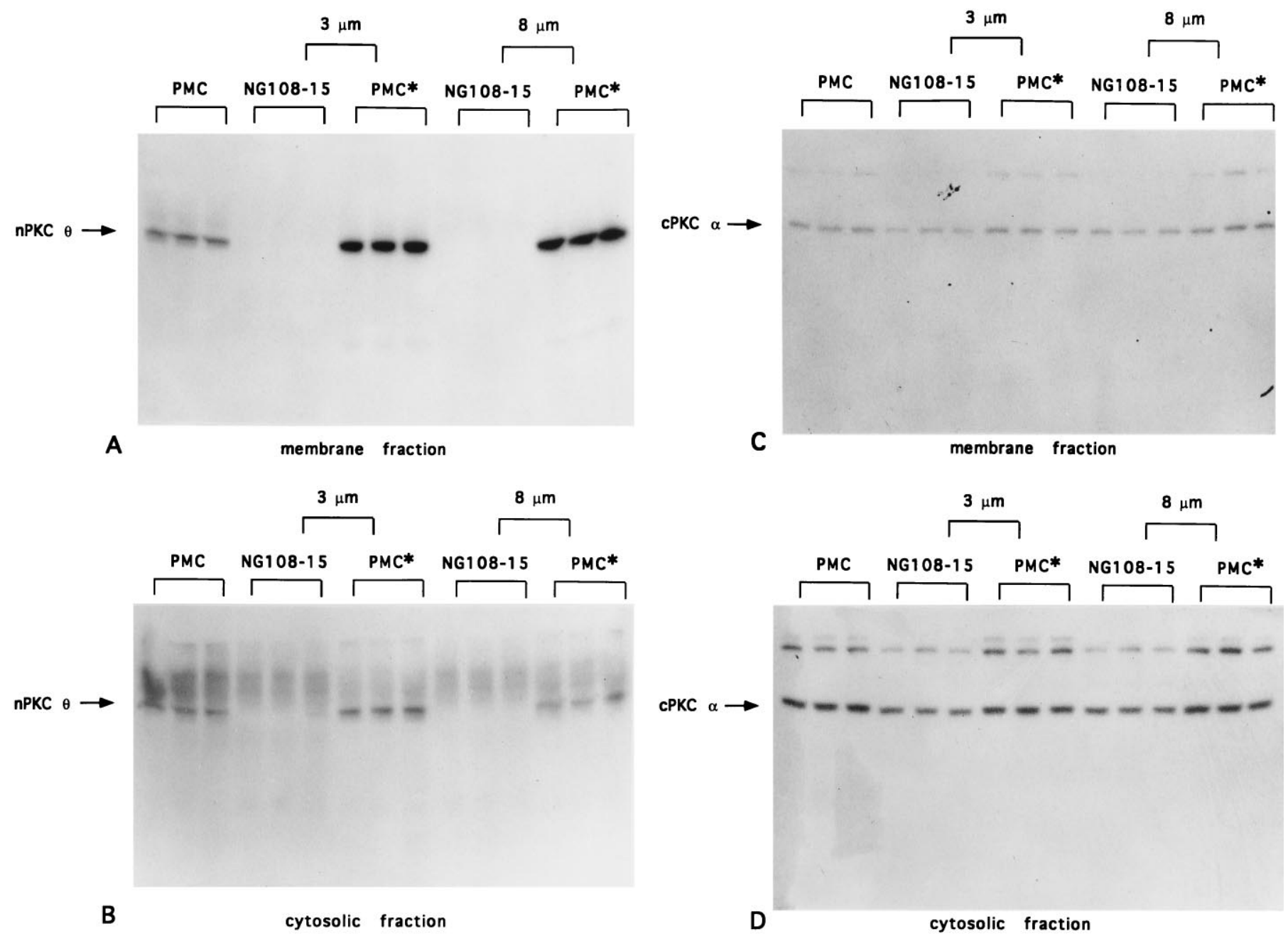

Figure 6. Effect of myotube indirect coculture with NG108-15 cells on PKC $\theta$ and $\alpha$ expression. Primary myoblast cultures were established and cultured for 7-8 d as described in the legend to Figure 2 . Myotubes were cultured in parallel for $2.5 \mathrm{~d}$ alone $(P M C)$ or were indirectly cocultured with $5 \times 10^{5}$ NG108-15 cells (NG108-15) separated from the myotubes $\left(P M C^{*}\right)$ by a semipermeable membrane of 3 or $8 \mu$ m pore size as indicated. After $3 \mathrm{~d}$, myotube cultures and NG108-15 and myotube indirect cocultures were each harvested separately and homogenized, and protein $(120 \mu \mathrm{g}$ for $\mathrm{nPKC} \theta, 50 \mu \mathrm{g}$ for $\mathrm{cPKC} \alpha$ ) from cytosolic and membrane fractions from each cell population was analyzed as described in the legend to Figure 1. Immunoblots were probed with anti-nPKC $\theta$ antiserum $(A, B)$ or anti-cPKC $\alpha$ antibody $(C, D)$ as described in the legend to Figure 2. Each lane represents a separate 35 mm tissue culture dish $(P M C)$ or cell populations present in separate compartments of individual coculture experiments performed in triplicate $\left(N G 108-15, P M C^{*}\right)$.

\section{DISCUSSION}

We investigated the cellular mechanisms that regulate PKC isoform expression in rat skeletal muscle. Our study focused on the most abundant PKC isoforms in skeletal muscle, nPKC $\theta$ and cPKC $\alpha$, members of the novel and classic categories of PKC, respectively. Our previous results demonstrated that $\mathrm{nPKC} \theta$ is enriched in skeletal muscle and is localized to the neuromuscular junction (Hilgenberg and Miles, 1995). We also showed a progressive increase in skeletal muscle expression of this isoform during early postnatal development. Based on these observations, we hypothesized that $\mathrm{nPKC} \theta$ plays a role in maturation of the neuromuscular junction and/or in signal transduction at this synapse.

To gain insight into the roles that these PKC isoforms play in skeletal muscle, we first sought to define the cellular mechanisms that regulate $\mathrm{PKC}$ isoform expression. Innervation has been shown to regulate the expression of numerous proteins in the neuromuscular junction (Brockes et al., 1975; Trimmer et al., 1990; Valenzuela et al., 1995). To determine whether innervation of skeletal muscle affects the expression of PKC isoforms, we denervated rat diaphragm muscle and observed that expression of nPKC $\theta$ decreased rapidly within the first week after denervation to early postnatal levels. Expression of nPKC $\theta$ diminished more rapidly than the enhanced expression of $\mathrm{nAChRs}$ induced by denervation of skeletal muscle (Merlie at al., 1984). In contrast, levels of cPKC $\alpha$ increased in denervated diaphragm muscle. Together, these data suggest that PKC isoform expression is regulated by nerve. Further support for this hypothesis was obtained by experiments in which nerve crush, resulting in a transient denervation of muscle, led to a complete recovery of PKC isoform levels with a time course consistent with that of reinnervation of skeletal muscle (Valenzuela et al., 1995). These data indicate that innervation can affect the expression of individual $\mathrm{PKC}$ isoforms in distinct ways, supporting the idea that PKC $\alpha$ and $\theta$ may perform different functions in developing and adult skeletal muscle.

Denervation deprives skeletal muscle of nerve-evoked contractile activity and of motor neuron-derived factors that influence 


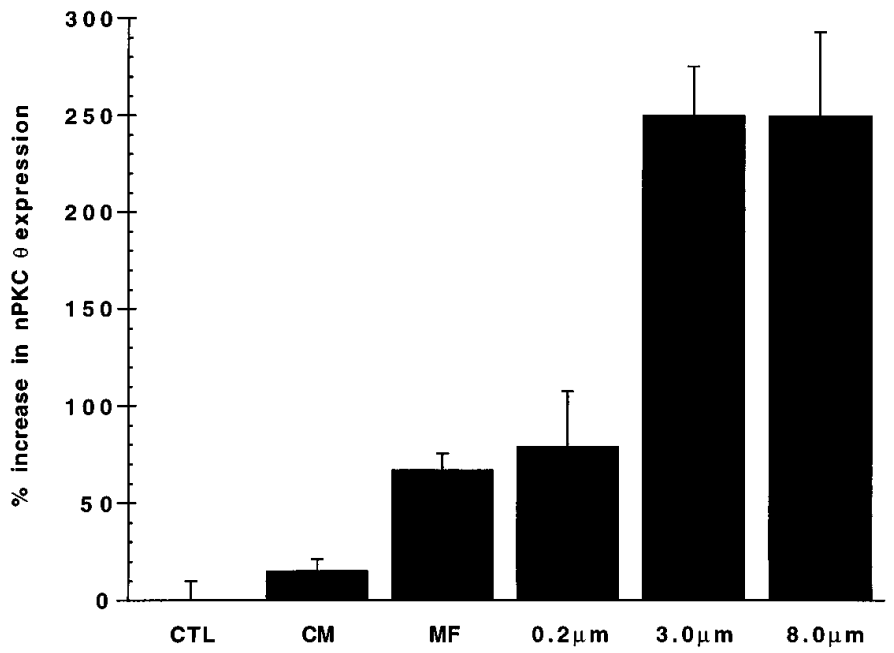

Figure 7. Quantitation of the effect of myotube culture with NG108-15 cell conditioned medium, NG108-15 cell subcellular membrane fraction, or NG108-15 cells on nPKC $\theta$ expression. Primary myoblast cultures were established and cultured for 7-8 d as described in the legend to Figure 2. Myotubes were cultured in parallel for $2.5 \mathrm{~d}$ alone $(C T L)$ or with conditioned medium $(C M)$ from, or the subcellular membrane fraction $(M F)$ from, $5 \times 10^{5}$ NG108-15 cells. Alternatively, myotubes were indirectly cocultured with $5 \times 10^{5}$ NG108-15 cells separated from the myotubes by a semipermeable membrane of the indicated pore size. Myotubes were homogenized, and equal protein $(120 \mu \mathrm{g})$ was analyzed as described in the legend to Figure 1. Data are expressed as percent increase in nPKC $\theta$ expression in cytosolic plus membrane fractions of experimental compared with control cultures. Each experiment was performed in triplicate except for control $(C T L)$ and $0.3 \mu \mathrm{m}$ filters where $n=15$ for each. Error bars represent SEM.

muscle development and maintain trophic interactions between these two tissues (Grinnell, 1995). To investigate factors that might maintain PKC isoform levels in skeletal muscle, we examined $\mathrm{PKC}$ isoform expression in rat primary myotube cultures that are not innervated. The subcellular distributions of $\mathrm{cPKC} \alpha$ in the cytosolic and nPKC $\theta$ in the membrane fractions of myotubes were found to be similar to the subcellular distributions of these two isoforms in adult skeletal muscle, suggesting that innervation does not play a role in regulating the subcellular distribution of these enzymes.

PKC isoform expression was examined in cells undergoing differentiation from myoblasts to myotubes in the absence of nerve. nPKC $\theta$ expression in myoblasts, at both the protein and the mRNA transcript level, was significantly below levels seen in adult skeletal muscle, and the increase in expression that occurred during differentiation suggests that this process is not sufficient to induce adult skeletal muscle levels of nPKC $\theta$. On the other hand, during myogenic differentiation, increased expression of $\mathrm{cPKC} \alpha$, to levels exceeding those in adult skeletal muscle, suggests that this enzyme may play a role in myogenesis. Although fibroblasts also express cPKC $\alpha$, the increased levels of this isoform found in primary myotube cultures could not be attributed to the presence of fibroblasts or to their proliferation over the culture period.

The differences seen in PKC $\alpha$ and $\theta$ levels in myotubes versus adult skeletal muscle lead to several hypotheses. PKC isoform expression in myotubes parallels PKC expression seen after skeletal muscle denervation and may indicate innervation-dependent regulation of PKC expression. Although it is possible that nerveevoked contraction influences PKC isoform expression, an alternative hypothesis is that nerve influences PKC $\alpha$ and $\theta$ expression in skeletal muscle by virtue of other interactions.

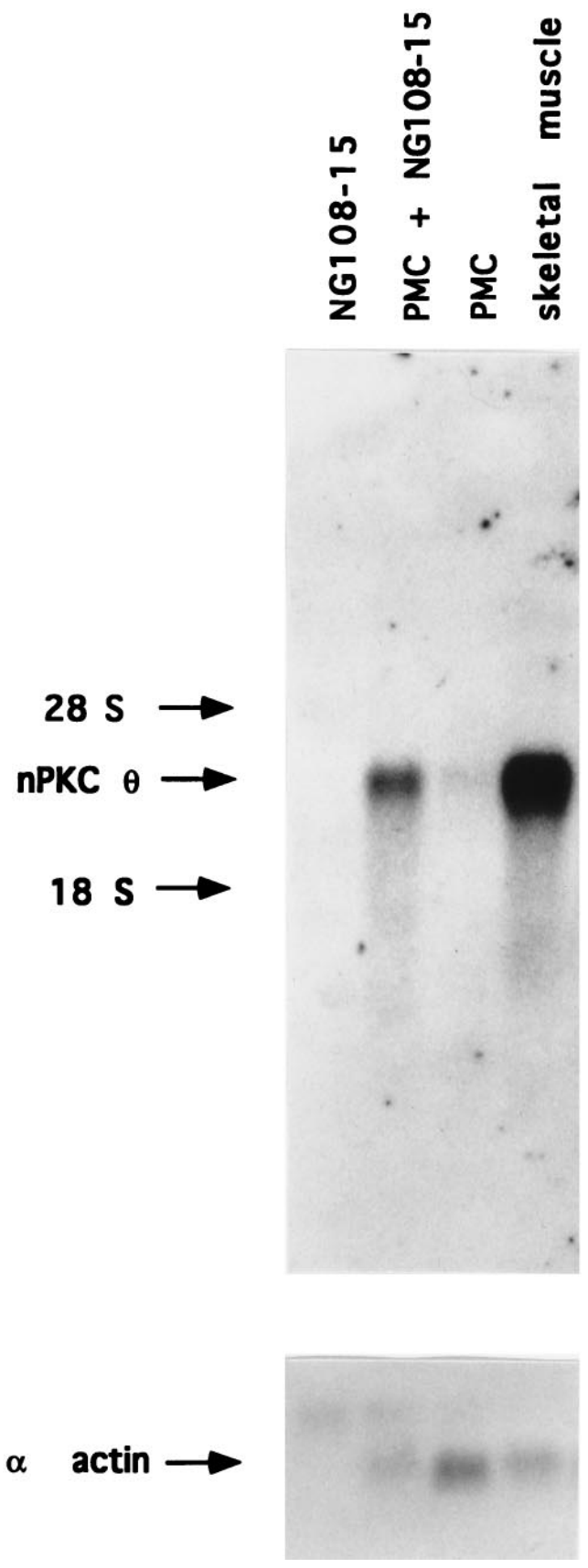

Figure 8. Effect of coculture of myotubes with NG108-15 cells on nPKC $\theta$ mRNA transcript expression. Primary myoblast cultures were established on $100 \mathrm{~mm}$ tissue culture dishes and cultured for $7 \mathrm{~d}$ as described in the legend to Figure 2. Myotubes were cultured in parallel for $2.5 \mathrm{~d}$ alone $(P M C)$ or in the presence of $1.4 \times 10^{6}$ NG108-15 cells $(P M C+$ NG108-15). An equal number of NG108-15 cells was cultured separately in parallel (NG108-15). Total RNA from each culture and from adult skeletal muscle was isolated and quantitated. Total poly $\left(\mathrm{A}^{+}\right)$-enriched RNA from each culture was isolated, electrophoresed, and transferred to nylon membranes. Adult skeletal muscle poly $\left(\mathrm{A}^{+}\right)$-enriched RNA, obtained from an amount of total RNA equal to that present in the myotube culture $(\sim 100 \mu \mathrm{g})(P M C)$, was loaded as a control (skeletal muscle). Blots were probed with ${ }^{32} \mathrm{P}$-labeled nPKC $\theta$ cDNA and exposed for autoradiography. Radioactivity was quantitated by PhosphorImager analysis using ImageQuant software. This figure represents one of three identical experiments in which the increase in nPKC $\theta$ mRNA in cocultured myotubes was 2.5 -fold \pm 0.44 SEM above control myotubes. The blot represented by the top panel of this figure was subsequently reprobed with ${ }^{32} \mathrm{P}$-labeled $\alpha$-actin cDNA. Arrow indicates skeletal muscle isoform of $\alpha$-actin mRNA transcripts. 


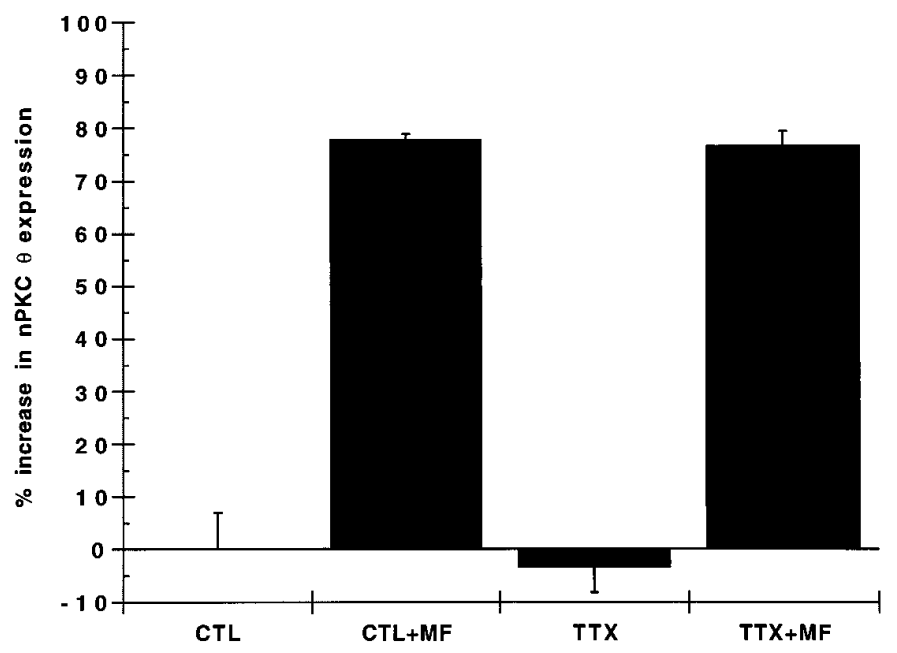

Figure 9. Effect of tetrodotoxin on myotube nPKC $\theta$ expression. Primary myoblast cultures were established and cultured for $7 \mathrm{~d}$ as described in the legend to Figure 2. Myotubes were preincubated for 3 hr with $(T T X)$ or without (CTL) $500 \mathrm{~nm}$ tetrodotoxin. The subcellular membrane fraction from $1 \times 10^{6} \mathrm{NG108-15}$ cells $(+M F)$ or buffer alone was added, and the cultures were incubated for $2 \mathrm{~d}$ in the continued presence of $500 \mathrm{~nm}$ tetrodotoxin. Myotube cultures were homogenized, and equal protein $(100 \mu \mathrm{g})$ was analyzed as described in the legend to Figure 1. Data are expressed as percent increase in nPKC $\theta$ expression in cytosolic plus membrane fractions of experimental compared with control $(C T L)$ cultures. Each experiment was performed in triplicate. Error bars represent SEM.

cPKC $\alpha$ levels may rise in denervated skeletal muscle because of the proliferation of muscle precursor cells (Hess and Rosner, 1970), similar to the proliferation of myoblasts that occurs in culture. PKC has been shown to play a role in myoblast fusion (David et al., 1990; Vaidya et al., 1991), and enhanced PKC activity in the soluble fraction of myotubes compared with myoblasts has been demonstrated (Adamo et al., 1989). Perhaps this activity is attributed to $\mathrm{cPKC} \alpha$. The skeletal muscle-specific transcription factor myogenin is a substrate for $\mathrm{PKC}$, and phosphorylation of myogenin by PKC causes the factor to lose DNAbinding activity (Olsen, 1992). It is possible that cPKC $\alpha$ plays a role in these early myogenic events that occur in the absence of nerve.

The expression of another skeletal muscle-specific protein kinase has been shown to be regulated by myogenic differentiation as well as by electrical activity. Recently, a receptor tyrosine kinase, MuSK, has been identified by cDNA cloning and revealed to be localized in the neuromuscular junction (Valenzuela et al., 1995). In contrast to nPKC $\theta$, MuSK mRNA transcript levels are highest in embryonic muscle and are downregulated postnatally in rat skeletal muscle. Similar to $\mathrm{cPKC} \alpha$, MuSK protein expression increases after axotomy or nerve crush and during differentiation of C2 myoblasts to myotubes. The functional role of MuSK and the underlying mechanisms regulating its expression in skeletal muscle have not been completely elucidated.

To examine whether the presence of nerve influences PKC expression in myotubes, we cocultured differentiated myotubes with NG108-15 cells. NG108-15 cells form functional cholinergic synapses on myotubes (Christian et al., 1977), and a factor from these cells promotes nAChR clustering (Christian et al., 1978). Coculture of myotubes with NG108-15 cells increases nAChR $\beta$ subunit tyrosine phosphorylation (K. Miles, unpublished observations), a phosphorylation pattern shared by mature nAChRs in the neuromuscular junction (Qu et al., 1990). NG108-15 cell coculture with myotubes may mimic other events that occur during synaptogenesis at the neuromuscular junction. Coculture of myotubes with NG108-15 cells significantly enhanced nPKC $\theta$ protein and mRNA transcript expression in myotubes. When the two cell populations were cultured together separated by a porous membrane, the increase in $\mathrm{nPKC} \theta$ expression in myotubes caused by NG108-15 cells appeared to be dependent on the pore size of the membranes separating myotubes from NG108-15 cells. This result suggests that cell contact as well as a diffusible factor(s) might be responsible for changes in nPKC $\theta$ expression. The observation that subcellular membrane fractions from NG108-15 cells increased nPKC $\theta$ expression in myotubes to the same extent as NG108-15 cells separated from myotubes by a $0.2 \mu \mathrm{m}$ filter supports this hypothesis. That $\mathrm{cPKC} \alpha$ levels in myotubes were unaltered by NG108-15 cells suggests that the factor(s) from nerve that increases PKC isoform expression in skeletal muscle is specific for $\mathrm{nPKC} \theta$. In addition, these results support the hypothesis that contact with nerve does not repress cPKC $\alpha$ expression in myotubes, although the possibility that an inhibitory factor is present in motoneurons and absent from NG108-15 cells has not been eliminated.

Despite the lack of synaptic contact, myotubes in culture are electrically active and contract spontaneously. Inhibition of contractile activity by blocking voltage-sensitive sodium channels had no effect on PKC expression in myotubes. Moreover, subcellular membrane fractions from NG108-15 cells retained their ability to increase $\mathrm{nPKC} \theta$ expression in electrically silent myotubes, further demonstrating that the effect of innervation on PKC expression is not likely to be mediated directly by muscle activity. Rather, the ability of nerve to contact muscle and increase nPKC $\theta$ expression may be attributable to another, as yet undefined, transynaptic interaction.

Certain molecules are known to affect gene expression transynaptically in skeletal muscle. ARIA, a factor belonging to the heregulin family of proteins, is thought to be synthesized and secreted by motor neurons into the extracellular matrix (Martinou et al., 1991; Corfas et al., 1995; Loeb and Fischbach, 1995). ARIA appears to transduce its signal intracellularly via the erbB family of receptor tyrosine kinases (Corfas et al., 1995) and increases both nAChR and voltage-sensitive sodium channel synthesis in myotubes (Corfas and Fischbach, 1993). In addition, calcitonin gene-related peptide, a neuropeptide present in motor neuron dense core vesicles (Villar et al., 1988), also increases nAChR synthesis by raising intracellular cAMP levels (New and Mudge, 1986).

The observation that nPKC $\theta$ expression, but not $\operatorname{cPKC} \alpha$, increases as a result of contact with a neuronal cell line supports the hypothesis that $\mathrm{nPKC} \theta$ plays a unique role in the neuromuscular junction. Although specific substrates for nPKC $\theta$ have not yet been identified, it is likely that ion channels, receptors, protein kinases, and phosphatases that are concentrated in the neuromuscular junction are substrates for $\mathrm{nPKC}$ $\theta$. For example, because phorbol ester activation of PKC in myotubes interrupts ARIA-induced autophosphorylation on tyrosyl residues of members of the erbB receptor family (Altiok et al., 1995), it is possible that nPKC $\theta$ is involved in downregulating the erbB receptors. In addition, nPKC $\theta$ may also be involved in modulating the signal transduction events initiated by agrin, as suggested by the evidence that phorbol ester treatment of myotubes inhibits both $\mathrm{nAChR}$ clustering and tyrosine phosphorylation induced by agrin (Wallace et al., 
1991). Perhaps nPKC $\theta$ kinase activity acts as a negative regulator to balance events associated with synapse formation and signal transduction at the neuromuscular junction.

\section{REFERENCES}

Adamo S, Caporale C, Nervi C, Ceci R, Molinaro M (1989) Activity and regulation of a calcium and phospholipid-dependent protein kinase in differentiating chick myogenic cells. J Cell Biol 108:153-158.

Altiok N, Bessereau J-L, Changeux J-P (1995) ErbB3 and ErbB2/neu mediate the effect of heregulin on acetylcholine receptor gene expression in muscle: differential expression at the endplate. EMBO J 14:4258-4266.

Baier G, Telford D, Giampa L, Coggeshall KM, Baier-Bitterlich G, Isakov N, Altman A (1993) Molecular cloning and characterization of PKC $\theta$, a novel member of the protein kinase $\mathrm{C}$ (PKC) gene family expressed predominantly in hematopoietic cells. J Biol Chem 268:4997-5004.

Bendahhou S, Cummins TR, Potts JF, Tong J, Agnew WS (1995) Serine1321 -independent regulation of the $\mu 1$ adult skeletal muscle $\mathrm{Na}^{+}$channel by protein kinase C. Proc Natl Acad Sci USA 92:12003-12007.

Brockes JP, Hall ZW (1975) Synthesis of acetylcholine receptors by denervated rat diaphragm muscle. Proc Natl Acad Sci USA 72:1368-1372.

Bursztajn S, Schneider LW, Jong Y-J, Berman SA (1988) Phorbol esters inhibit the synthesis of acetylcholine receptors in cultured muscle cells. Biol Cell 63:57-65.

Caratsch CG, Grassi F, Molinaro M, Eusebi F (1986) Postsynaptic effects of the phorbol ester TPA on frog end-plates. Eur J Physiol 407:409-413.

Chang JD, Xu Y, Raychowdhury MK, Wore JA (1993) Molecular cloning and expression of a cDNA encoding a novel isoenzyme of a protein kinase C (nPKC $\theta$ ). J Biol Chem 268:14208-14214.

Christian CN, Nelson PG, Peacock J, Nirenberg M (1977) Synapse formation between two clonal cell lines. Science 196:995-998.

Christian CN, Daniels MP, Sugiyama H, Vogel Z, Jacques L, Nelson PG (1978) A factor from neurons increases the number of acetylcholine receptor aggregates on cultured muscle cells. Proc Natl Acad Sci USA 75:4011-4015.

Corfas G, Fischbach GD (1993) The number of $\mathrm{Na}^{+}$channels in cultured chick muscle is increased by ARIA, an acetylcholine receptor-inducing activity. J Neurosci 13:2118-2125.

Corfas G, Rosen KM, Aratake H, Krauss R, Fischbach GD (1995) Differential expression of ARIA isoforms in the rat brain. Neuron 14:103-115.

David JD, Faser CR, Perrot GP (1990) Role of protein kinase C in chick embryo skeletal myoblast fusion. Dev Biol 139:89-99.

Eusebi F, Molinaro M, Zani BM (1985) Agents that activate protein kinase $\mathrm{C}$ reduce acetylcholine sensitivity in cultures myotubes. J Cell Biol 100:1339-1342.

Evans S, Goldman D, Heinemann S, Patrick J (1987) Muscle acetylcholine receptor biosynthesis. J Biol Chem 262:4911-4916.

Grinnell AD (1995) Dynamics of nerve-muscle interaction in developing and mature neuromuscular junctions. Physiol Rev 75:789-834.

Hess A, Rosner S (1970) The satellite cell bud and myoblast in denervated mammalian muscle fibers. Am J Anat 129:21-39.

Hilgenberg L, Miles K (1995) Developmental regulation of a protein kinase $\mathrm{C}$ isoform localized in the neuromuscular junction. J Cell Sci 108:51-61.

Huang C-F, Tong J, Schmidt J (1992) Protein kinase C couples membrane excitation to acetylcholine receptor gene inactivation in chick skeletal muscle. Neuron 9:671-678.

Hug H, Sarre TF (1993) Protein kinase C isoenzymes: divergence in signal transduction? Biochem J 291:329-343.

Klarsfeld A, Laufer R, Fontaine B, Devillers-Thiery A, Dubreuil C, Changeux J-P (1989) Regulation of muscle AChR $\alpha$ subunit gene expression by electrical activity: involvement of protein kinase and $\mathrm{Ca}^{2+}$. Neuron 2:1229-1236.

Leach KL, Powers EA, McGuire JC, Dong L, Kiley SC, Jaken S (1988) Monoclonal antibodies specific for type 3 protein kinase $\mathrm{C}$ recognize distinct domains of protein kinase $\mathrm{C}$ and inhibit in vitro functional activity. J Biol Chem 263:13223-13230.
Leader DP, Gall I, Campbell PC (1986) The structure of a cDNA clone corresponding to mouse cardiac muscle actin mRNA. Biosci Rep 6:741-747.

Loeb JA, Fischbach GD (1995) ARIA can be released from extracellular matrix through cleavage of a heparin-binding domain. J Cell Biol 130:127-135.

Martinou J-C, Falls DL, Fischbach GD, Merlie JP (1991) Acetylcholine receptor-inducing activity stimulates expression of the $\epsilon$-subunit gene of the muscle acetylcholine receptor. Proc Natl Acad Sci USA 88:7669-7673.

Merlie JP, Isenberg KE, Russell SD, Sanes JR (1984) Denervation supersensitivity in skeletal muscle: analysis with a cloned cDNA probe. $\mathrm{J}$ Cell Biol 99:332-335.

Mileo AM, Palma E, Polenzani L, Limatols C, Grassi F, Eusebi F (1995) Protein kinase $\mathrm{C}$ modulates exogenous acetylcholine current in Xenopus oocytes. J Neurosci Res 41:443-451.

Miles K, Huganir RL (1988) Regulation of nicotinic acetylcholine receptors by protein phosphorylation. Mol Neurobiol 2:91-124.

Miles K, Audigier SM, Greengard P, Huganir R (1994) Autoregulation of phosphorylation of the nicotinic acetylcholine receptor. J Neurosci 14:3271-3279.

Mischak H, Goodnight J, Henderson DW, Osada S-I, Ohno S, Mushinski JF (1993) Unique expression pattern of protein kinase C- $\theta$ : high mRNA levels in normal mouse testes and in T-lymphocyte cells and neoplasms. FEBS Lett 326:51-55.

New HV, Mudge AW (1986) Calcitonin gene-related peptide regulates muscle acetylcholine receptor synthesis. Nature 323:809-811.

Newton AC (1995) Protein kinase C: structure, function and regulation. J Biol Chem 270:28495-28498.

Nishizuka Y (1992) Intracellular signaling by hydrolysis of phospholipids and activation of protein kinase C. Science 258:607-614.

Numann R, Hauschka SD, Catterall WA, Scheuer T (1994) Modulation of skeletal muscle sodium channels in a satellite cell line by protein kinase C. J Neurosci 14:4226-4236.

Olson EN (1992) Interplay between proliferation and differentiation within the myogenic lineage. Dev Biol 154:261-272.

Osada S-I, Mizuno K, Saido C, Suzuli K, Kuroki T, Ohno S (1992) A new member of the protein kinase $\mathrm{C}$ family, nPKC $\theta$, predominantly expressed in skeletal muscle. Mol Cell Biol 12:3930-3938.

Qu Z, Moritz E, Huganir RL (1990) Regulation of tyrosine phosphorylation of the nicotinic acetylcholine receptor at the rat neuromuscular junction. Neuron 4:367-378.

Ross A, Rapuano M, Prives J (1988) Induction of phosphorylation and cell surface redistribution of acetylcholine receptors by phorbol esters and carbamylcholine in chick muscle cells. J Cell Biol 107:1139-1145.

Safran A, Sagi-Eisenberg R, Neumann D, Fuchs S (1987) Phosphorylation of the acetylcholine receptor by protein kinase $\mathrm{C}$ and identification of the phosphorylation site within the receptor $\delta$ subunit. J Biol Chem 262:10506-10510.

Schmidt J, Raftery MA (1973) A simple assay for the study of solubilized acetylcholine receptors. Anal Biochem 52:349-351.

Trimmer JT, Cooperman SS, Agnew WS, Mandel G (1990) Regulation of muscle sodium channel transcripts during development and in response to denervation. Dev Biol 142:360-367.

Vaidya TB, Weyman CM, Teegarden D, Ashendel CL, Taparowsky EJ (1991) Inhibition of myogenesis by the H-ras oncogene: implication of a role for protein kinase C. J Cell Biol 4:809-820.

Valenzuela DM, Stitt TN, DiStefano PS, Rojas E, Mattsson K, Compton DL, Nunez L, Park JS, Stark JL Gies DR, Thomas S, LeBeau MM, Fernald AA, Copeland NG, Jenkins NA, Burden SJ, Glass DJ, Yancopoulos GD (1995) Receptor tyrosine kinase specific for the skeletal muscle lineage: expression in embryonic muscle at the neuromuscular junction, and after injury. Neuron 15:573-584.

Villar MJ, Huchet M, Hökfelt T, Changeux JP, Fahrenkrug J, Brown JC (1988) Existence and coexistence of calcitonin gene-related peptide, vasoactive intestinal peptide and somatostatin-like immunoreactivities in spinal cord motoneurons of developing embryos and post-hatch chicks. Neurosci Lett 86:114-118.

Wallace BG, Qu Z, Huganir RL (1991) Agrin induces phosphorylation of the nicotinic acetylcholine receptor. Neuron 6:869-878. 